\title{
Consumers and Brands Across the Globe: Research Synthesis and New Directions
}

\author{
Zeynep Gürhan-Canli, Gülen Sarıal-Abi, and Ceren Hayran
}

\begin{abstract}
Extensive research has investigated branding practices, processes, and consumers' reactions to brands in a globalized world. In this review, the authors aim to organize and synthesize the growing literature on branding, culture, and globalization from a behavioral perspective by reviewing 129 articles published over 25 years. Specifically, they explicate two perspectives found in the literature: (1) global-local branding and (2) the influence of culture on consumer and brand interactions. The authors identify conceptual gaps in the literature and discuss how new realities in the macro environment (e.g., political issues, digital transformation, environmental concerns) may affect the interaction between culture, brands, and consumers in a globalized world. This review facilitates a more impactful future research agenda in both theory and practice at the interface of branding and globalization from the perspective of behavioral outcomes.
\end{abstract}

Keywords: globalization, global brands, local brands, culture

Online Supplement: http://dx.doi.org/10.1509/jim.17.0063

$\mathrm{H}$ ow consumers evaluate brands and respond to different branding practices has been a central topic in the marketing literature for decades. Since the acceleration of globalization in the 1990s, researchers have examined the antecedents and consequences of consumers' evaluations of various branding practices across cultures. Extant research has focused on global versus local branding as well as cross-cultural similarities and differences in response to branding efforts. In this review, we organize and synthesize the growing body of research at the intersection of branding, culture, and globalization. We review published research in the influential academic journals focusing on branding and culture in a globalized world. We identify missing conceptual linkages in the literature and discuss future research opportunities in response to recent global macro changes.

A synthesis of existing research on branding, culture, and globalization is important and timely for at least two main reasons. First, an impressive amount of research has been

Zeynep Gürhan-Canli is Dean and Migros Professor of Marketing, Koç University (email: zcanli@ku.edu.tr). Gülen Sarıal-Abi is Assistant Professor of Marketing, Bocconi University (email: gulen.sarialabi@ unibocconi.it). Ceren Hayran is Assistant Professor of Marketing, Özyeğin University (email: ceren.hayran@ozyegin.edu.tr). Matthew Robson served as associate editor for this article. published over the past 25 years, during which globalization has affected branding practices significantly. However, only limited research efforts have focused on synthesizing this body of literature (Chabowski, Samiee, and Hult 2013; Özsomer and Altaras 2008; Whitelock and Fastoso 2007). Our study differs from the existing syntheses on global branding by analyzing the literature from a behavioral perspective. An integrative review of research on global branding, culture, and consumer behavior is useful to determine what has been studied as well as what is missing in the literature, facilitating the identification of promising avenues of future research in this area.

Second, globalization is being questioned in different parts of the world particularly because of its role in causing increasing inequalities in wealth distribution, environmental degradation, and the rise of populist political movements. At the same time, markets and individuals are more integrated than ever, thanks to advances in technology and

Journal of International Marketing

(C2018, American Marketing Association

Vol. 26, No. 1, 2018, pp. 96-117

DOI: $10.1509 /$ im.17.0063

ISSN 1069-031X (print) 1547-7215 (electronic) 
telecommunications. These new realities are likely to influence the interactions between consumers and brands within and across cultures, necessitating new research efforts. Consequently, a synthesis of research can facilitate the development of new research ideas when existing findings are analyzed in relation to the current trends and expectations regarding cultural influences and globalization.

This study adds to the existing literature on culture and global marketing in several ways. First, we aim to contribute to the analyses of literature on global branding (e.g., Chabowski, Samiee, and Hult 2013; Özsomer and Altaras 2008; Whitelock and Fastoso 2007) by focusing on the consumer-brand relationship aspect. Conceptually, our review differs from the previous scholarly reviews by focusing on behavioral outcomes, attitudes, perceptions, and beliefs. Our review is also different in terms of its methodological approach. For example, Chabowski, Samiee, and Hult (2013) conducted a bibliometric analysis of the global branding literature through cocitation analysis. Whereas we scanned the preselected journals with keywords that were chosen a priori, Chabowski, Samiee, and Hult reviewed articles that were selected by using search words proposed by global branding experts in the field, and they included the most cocited publications in their analyses. In one of the initial reviews of global branding literature, Whitelock and Fastoso (2007) conducted a content analysis by using preselected keywords and journals and outlined the most frequently analyzed research topics. In contrast, Özsomer and Altaras (2008) conducted an integrative conceptual review on global branding through the lens of three specific theoretical approaches-consumer culture theory (CCT), signaling theory, and the associative network memory model-focusing on two outcomes: global brand attitude and global brand purchase likelihood. Compared with Özsomer and Altaras's work, our synthesis uses a different set of theoretical frameworks and examines a greater number of consumer-related outcomes. These and other scholarly reviews successfully analyzed global branding literature from different aspects and suggested diverse fruitful research avenues. We hope that our review provides further insights and addresses different research gaps in global branding literature.

Second, we contribute to the literature by synthesizing the fragmented topics and issues. Our review suggests that current research can be categorized under two perspectives. One perspective focuses predominantly on global and local branding as either independent or dependent variables, and the other perspective investigates the crosscultural and country differences and similarities in understanding consumers' relationships with brands. Within each perspective, we identify the groups of variables that influence consumers' evaluations of branding practices as well as the underlying processes. This review helps us identify which factors are emphasized within each domain. We also demonstrate that previous literature has mainly benefited from consumer information processing, self and identity theory, CCT, and psycholinguistics in psychology.

Third, we suggest that previous research has overlooked some areas (the role of affective processes underlying consumer responses to global and local brands across cultures and cross-cultural differences in consumer-brand relationships). By reviewing a wide variety of publications over 25 years, we aim to facilitate a more impactful future research agenda at the interface of branding and globalization from the perspective of behavioral outcomes. We also discuss recent developments in global markets (threatening environment with terrorist attacks, interconnectedness of the real and virtual life, polarization, increased nationalism, and the rise of sharing economy) and identify related future research opportunities.

\section{LITERATURE SEARCH METHOD}

Our search targeted articles examining variables related to research at the intersection of consumers, brands, and culture. To be eligible for inclusion, articles had to have been published in these journals: Journal of International Marketing, Journal of Consumer Research, Journal of Consumer Psychology, Journal of Marketing, Journal of Marketing Research, International Journal of Research in Marketing, Journal of the Academy of Marketing Science, International Marketing Review, and Journal of International Business Studies. These are recognized outlets for research on consumers and brands across the globe. Our time frame covers articles published from 1992 to 2016. Although we are fully aware that we may not have captured all the existing literature on this topic, we did cover several influential articles in the field with high numbers of citations.

We first compiled all the articles published in the aforementioned journals using the following keywords in their abstracts in the EBSCO database: "brand" and "consumer," and "global," "culture," "country," or "cultural." Because our focus is to provide a synthesis of the literature by examining the role of culture in global branding and consumer behavior research, we mainly focused on studies that investigated the intersection of global branding, culture, and consumer behavior. After we removed duplicates and articles that did not have a branding focus or that presented case 
studies, this compilation yielded a total of 98 articles. A preliminary review of these articles revealed that a substantial body of research has examined global branding as a distinct phenomenon. Therefore, we subsequently cross-checked our list with another search list that focused on "global branding" and added 31 articles to the list. All the authors reviewed these articles and discussed different possibilities for organizing them. Our analyses indicated two research perspectives examined in the literature (see the Web Appendix).

The first perspective includes research on the rise of a global consumer culture and examines consumers' beliefs about, and attitudes and behaviors toward, global and local brands (Figure 1). Research on global and local branding emphasizes topics such as product, category (e.g., hedonic vs. utilitarian products), and attribute characteristics (e.g., quality attributes) relatively more and has a more managerial focus. In this perspective, we do not include articles with a strategy focus but solely elaborate on global branding articles that use consumer behavior-related outcomes. The second perspective focuses on research examining cross-cultural and country differences in consumers' responses to brand practices (e.g., brand extensions; see Figure 2). This perspective does not necessarily include articles with a global branding focus but examines differences in consumer-brand relationships across cultures. It explores how cultural dimensions and country characteristics interact with other brand-related, consumer-related, and contextual variables. It also focuses relatively more on understanding the underlying psychological processes. Within each perspective, we categorize the current literature on the basis of the different theoretical frameworks each has used (i.e., consumer information processing, self and identity, CCT, and psycholinguistics).

In the following section, we first discuss each research perspective (i.e., global and local branding and cultural influences on consumer-brand interactions). Within each research perspective, we categorize the published articles by the theoretical frameworks they use and identify what is missing in theory and in practice.

\section{RESEARCH PERSPECTIVE 1: GLOBAL AND LOCAL BRANDING}

With the rise of globalization in the early 1990s, scholars began to recognize the global consumer culture. Global brands serve different geographical regions with the same brand name and similar marketing strategies and characterize an important aspect of global consumer culture. Local brands, in contrast, are marketed in a specific country or a geographic area. Alden, Steenkamp, and Batra (1999) demonstrated that several brands use global consumer culture positioning to appeal to consumers who identify with a global culture due to the expanding interrelations of multiple cultures.

Subsequent research has explored several interesting issues. These include measures of global and local brand perceptions (Fischer, Völckner, and Sattler 2010; Lehmann, Keller, and Farley 2008; Strizhakova, Coulter, and Price 2008b; Swoboda and Hirschmann 2016), image and identity issues (e.g., global orientation, global cultural identity, world mindedness; Allman et al. 2016; Nijssen and Douglas 2011; Strizhakova and Coulter 2013), and cognitive and affective reactions (Dimofte, Johansson, and Ronkainen 2008). Other research areas include consumer commitment, brand choice, and purchase intentions (Davvetas, Sichtmann, and Diamantopoulos 2015; Eisingerich and Rubera 2010; Özsomer and Altaras 2008; Strizhakova and Coulter 2015; Torelli et al. 2012); demographic and ethnic correlates with global and local product and brand preferences (Dimofte, Johansson, and Bagozzi 2010; Strizhakova, Coulter, and Price 2012); which attributes consumers accord more importance when evaluating global and local brands (Van der Lans, Van Everdingen, and Melnyk 2016); and benefits and costs of global versus local branding and cultural iconicity (Özsomer 2012; Steenkamp and De Jong 2010; Thompson and Arsel 2004; Westjohn et al. 2016).

We suggest that the literature on global and local branding can be divided into three phases (i.e., 1990s, 2000 through 2010, and 2010 and onward), and each of these phases has a somewhat different research focus and varied theoretical frameworks. In our review of the literature (Figure 1), we found that during the early 1990s, research on global and local branding mostly used information processing theories to investigate the effects of brand-related factors (Häubl and Elrod 1999), attribute types (Ulgado and Lee 1993), and country-of-origin (COO) effects (Nebenzahl and Jaffe 1996; Tse and Gorn 1993; Tse and Lee 1993) on perceptions, beliefs, attitudes, and behavioral outcomes. In the early 2000s through the beginning of 2010, research on global and local branding was mainly dominated by the global CCT (Alden, Steenkamp, and Batra 2006; Batra et al. 2000; Cayla and Eckhardt 2008; Kjeldgaard and Askegaard 2006; Özsomer and Altaras 2008; Strizhakova, Coulter, and Price 2008b; Thompson and Arsel 2004). Finally, in the 2010s, researchers continued to draw on information processing theories to investigate brand-related factors such as brand origin and perceived brand foreignness (Balabanis and Diamantopoulos 2011; Heinberg, Ozkaya, and Taube 2016; Özsomer 2012; Swoboda and Hirschmann 2016; Swoboda, Pennemann, and Taube 2012; Xie, Batra, and 
Figure 1. Constructs Used in Global and Local Branding Literature

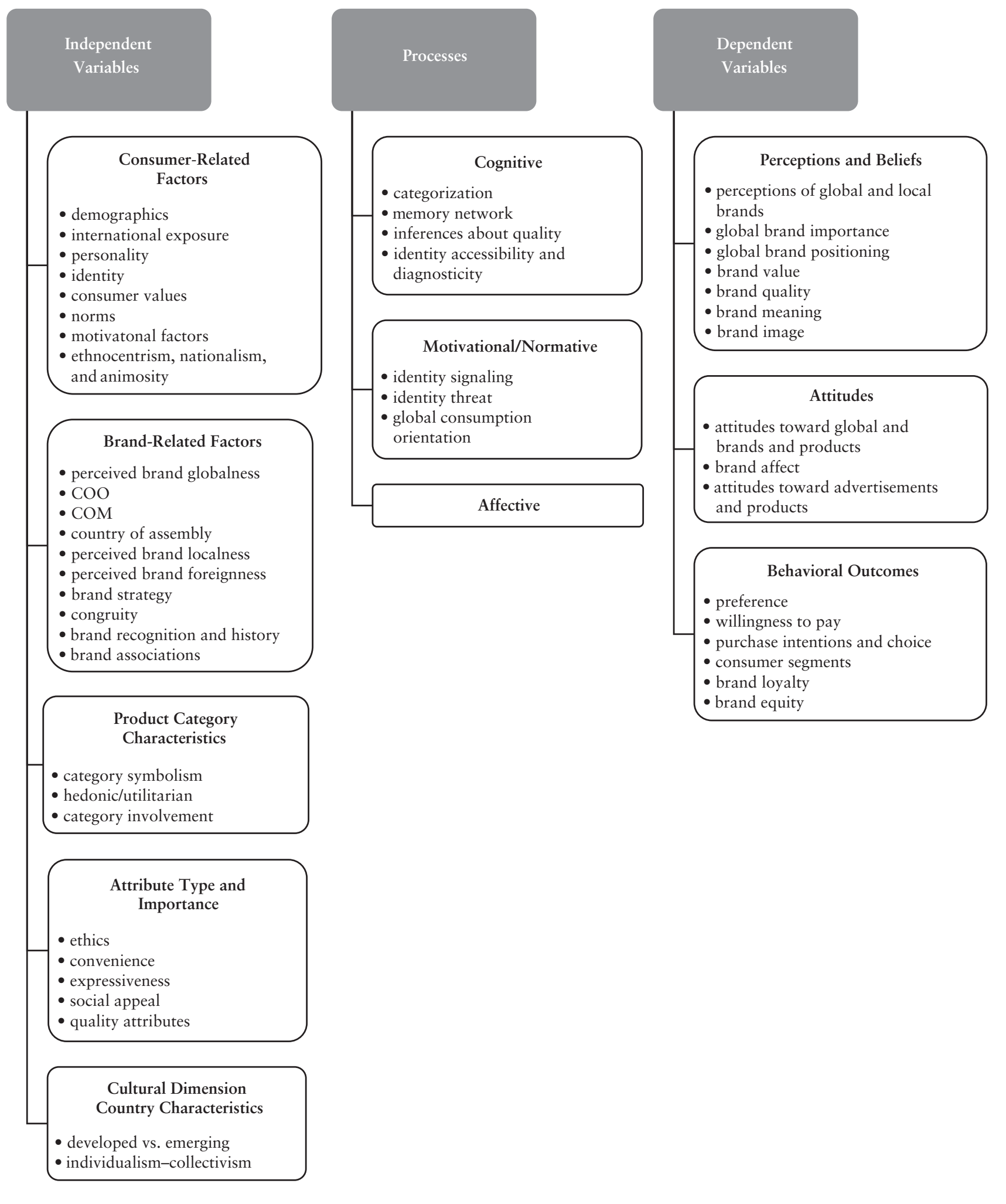


Figure 2. Constructs Used in Literature on Culture and Consumer-Brand Interactions

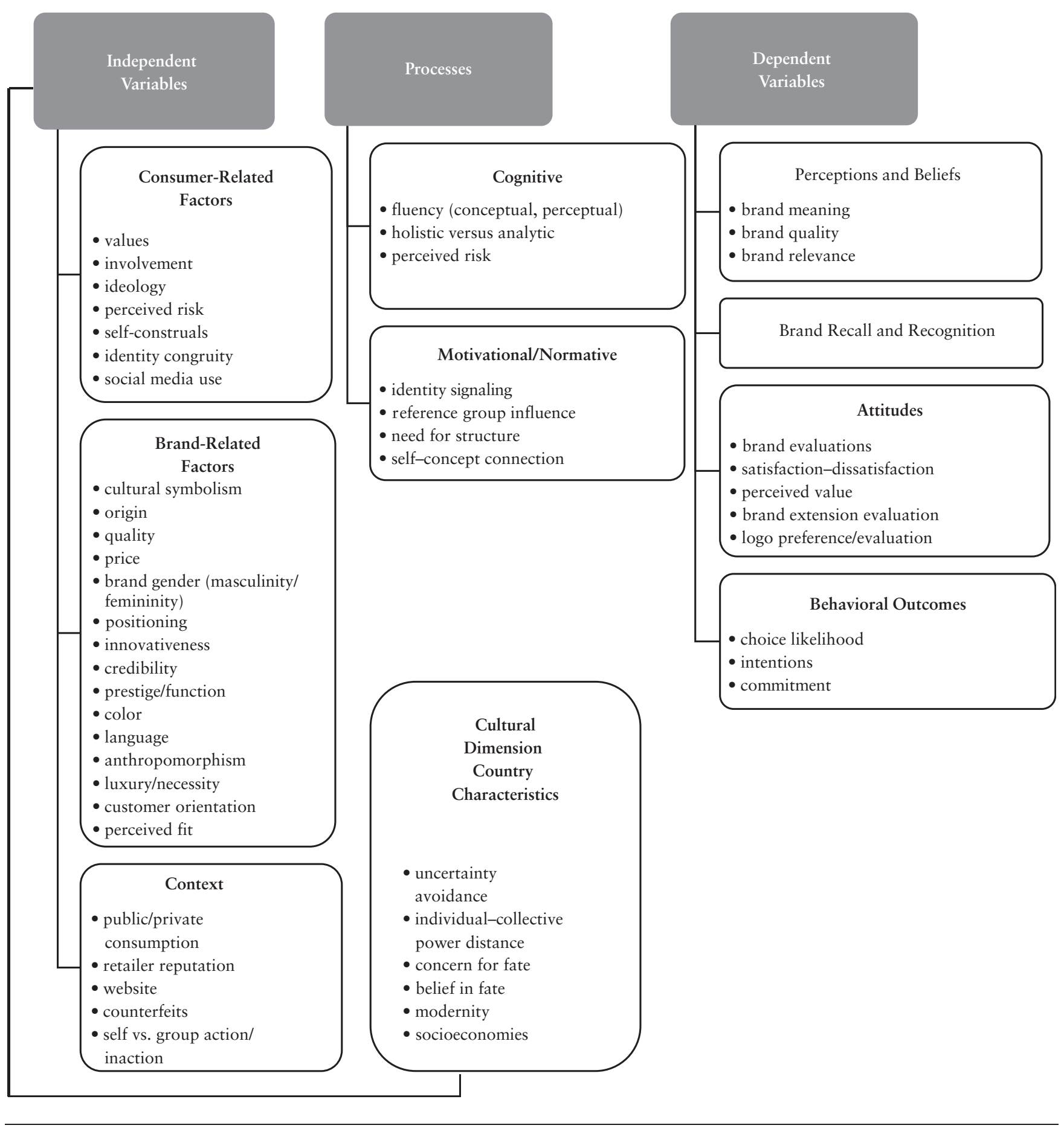

Peng 2015; Zhou, Yang, and Hu 2010), while COO research continued as well (Koschate-Fischer, Diamantopoulos, and Oldenkotte 2012; Martín and Cerviño 2011). Recent research has also focused on investigating global and local identity issues (Guo 2013; Strizhakova and Coulter 2013; Strizhakova, Coulter, and Price 2011, 2012; Tu, Khare, and Zhang 2012) and corporate social responsibility (CSR) practices (Madden, Roth, and Dillon 2012; Torres et al. 2012). 
In the subsequent sections, we first provide an overview of the research on global and local branding by presenting research findings based on different theoretical approaches (see the Web Appendix). More specifically, we discuss research on global and local branding that benefited from (1) consumer information processing literature (e.g., knowledge accessibility in cognition, categorization, schemas, stereotyping, consumer memory), (2) self and identity literature (e.g., ethnocentrism, animosity, regulatory focus), (3) CCT, and (4) psycholinguistics theories. Then, we identify and discuss the gaps in the literature.

\section{CURRENT LITERATURE ON GLOBAL AND LOCAL BRANDING BASED ON THEORETICAL APPROACHES}

\section{Consumer Information Processing}

The role of category accessibility and schemas on judgment, attitudes, and behavior has been at the core of information processing literature. In the global and local branding research, stereotyping literature has been used extensively to investigate the role of $\mathrm{COO}$, globalness, and product experience on product evaluations.

Other research has used categorization and schema theory to understand consumers' reactions to global and local branding. More specifically, drawing on categorization and schemata, researchers investigated the effects of perceived brand foreignness on brand value (Zhou, Yang, and $\mathrm{Hu}$ 2010), globalization attitude and global consumption orientation on global brand evaluation (Riefler 2012), functional and symbolic category properties on global and local brand choice (Davvetas and Diamantopoulos 2016), and the role of perceived brand globalness on loyalty (Swoboda and Hirschmann 2016). Additional research has explored the role of accessibility and diagnosticity of global and local identities on assimilative or contrastive evaluation (Zhang and Khare 2009) and the role of accessibility and diagnosticity of perceived brand globalness and localness on retail patronage (Swoboda, Pennemann, and Taube 2012).

Research has also demonstrated the effects of brand image and product experience on attribute evaluations, confidence, and product evaluations (Tse and Lee 1993); brand and country-of-manufacturing (COM) information as well as specific attribute information on product evaluations (Ulgado and Lee 1993); and incongruence between implied and actual COO on purchase likelihood (Melnyk, Klein, and Völckner 2012) using information processing theories such as cue utilization, accessibility, and diagnosticity (Okazaki 2006).
In addition to the role of knowledge accessibility in cognition and behavior, research has investigated the role of memory in global and local branding. Most of the research in this stream uses associative memory network theory (Hsieh 2002; Madden, Roth, and Dillon 2012; Özsomer 2012; Özsomer and Altaras 2008). Namely, researchers investigated the roles of product quality and corporate social responsibility on willingness to recommend (Madden, Roth, and Dillon 2012); global brand authenticity, credibility, quality, and prestige on global brand purchase likelihood (Özsomer and Altaras 2008); perceived brand globalness on purchase of a global brand in the presence of a local brand (Ozsomer 2012); and brand image multidimensionality across markets (Hsieh 2002).

Country of origin, whether it is where the brand originated or where products are manufactured, has become more important in the context of globalization. The "COO effect" refers to the extent to which consumer attitudes, preferences, and purchasing decisions are determined by the $\mathrm{COO}$ of the brand or the product. While there is extensive literature on $\mathrm{COO}$ effects, we specifically review articles that investigate the role of $\mathrm{COO}$ in relation to branding.

Early research on $\mathrm{COO}$ and branding practices focused mostly on how consumers evaluate the quality of binational products when they provide different pieces of information (Ulgado and Lee 1993). With the emergence of global brands, COO literature has also changed its focus. Researchers demonstrated the effects of actual COO and implied COO (Melnyk, Klein, and Völckner 2012), the impact of the congruity between the brand name and the country of production on consumers' product quality judgments (Häubl and Elrod 1999), and the differences between the COO effect and the global brand name effect (Tse and Gorn 1993). The literature has also explored how different labels such as "made in" a country versus "components from" or "is assembled in" has influenced consumer perceptions (Tse and Lee 1993), how consumers use country-specific associations for brand recognition and brand ownership (Herz and Diamantopoulos 2013), how brand origin misclassification and nonclassification influence consumers' brand image evaluations (Balabanis and Diamantopoulos 2011), and how COO affects willingness to pay for a product or a brand (Koschate-Fischer, Diamantopoulos, and Oldenkotte 2012).

The literature suggests that COO influences consumers' attitudes, intentions, purchase likelihoods, and willingness to pay in the global era when the COM, country of assembly, and brand's origin could all differ. Country-of-origin effects are mediated by cognitive and affective brand evaluations on 
brand-related outcomes. Affective (vs. cognitive) processes appear more important for hedonic (vs. utilitarian) products (Melnyk, Klein, and Völckner 2012). The effect of COO is reduced for high-involvement products when brand familiarity is high (Koschate-Fischer, Diamantopoulos, and Oldenkotte 2012). When brand name and COM are the only pieces of information, consumers use both pieces of information when evaluating a product, whereas they rely on brand name information when specific product attribute information as well as the brand name and the COM are available (Ulgado and Lee 1993). Domestic and foreign food products elicit different perceptions of healthiness (Gineikiene, Schlegelmilch, and Ruzeviciute 2016). Specifically, consumers are likely to prefer domestic food products because they perceive them as healthier and more natural.

Brand origin misclassification and nonclassification also influence consumers' brand image evaluations (Balabanis and Diamantopoulos 2011). Specifically, both misclassification and nonclassification have negative effects on brand evaluations. Similarly, the incongruence between the actual COO and the implied COO decreases the purchase likelihood asymmetrically: whereas incongruence has no effect on utilitarian categories, it backfires in hedonic categories. Researchers have benefited from brand equity concept in investigating the role of product, corporate, and country image on brand purchase behavior (Hsieh, Pan, and Setiono 2004) and the role of brand associations and brand recognition on global brand equity measurement (Hsieh 2004). Further research has investigated the effect of corruption in emerging countries on brand value (Lin and Chuang 2016), different brand metrics on portrayal of brands across different countries and categories (Lehmann, Keller, and Farley 2008); and the effect of CSR activities on brand equity (Torres et al. 2012).

\section{Self and Identity}

Decades of research on self-concept and identity have provided clear understanding that identity significantly influences consumer behavior. Researchers have used self and identity theories to understand how consumers evaluate global and local brands (Funk et al. 2010). Importantly, consumers' evaluation of global brands is contingent on their attitudes toward globalization (Riefler 2012). In addition, the literature has examined animosity and ethnocentrism as key constructs that can be conceptualized in relation to self and identity.

Consumers with an accessible global identity are likely to prefer a global product, and consumers with an accessible local identity tend to prefer a local product (Zhang and
Khare 2009). The perceived globalness of the local brand is positively related to local iconness in an emerging market, whereas the relationship is negative in advanced markets. Brand globalness and perceived brand localness can also enhance a brand's identity expressiveness (Xie, Batra, and Peng 2015).

Country-of-origin effects on branding are closely linked to consumer ethnocentrism (i.e., consumer perceptions about the superiority of domestic products/brands and the reluctance to purchase foreign products/brands to protect the domestic economy and living standards; Shimp and Sharma 1987; Winit et al. 2014) and consumer animosity (i.e., refusal to purchase brands/products from countries based on the animosity felt; Harmeling, Magnusson, and Singh 2015; Klein 2002; Klein, Ettenson, and Morris 1998). Because consumer ethnocentrism is an important construct that influences consumer reaction to brands in a global context, scholars have created measures (e.g., CETSCALE; Shimp and Sharma 1987) and discussed the theoretical antecedents of consumer ethnocentricity (Sharma, Shimp, and Shin 1995). Moreover, research has demonstrated the effect of consumer ethnocentrism on preference for local and global brands (Strizhakova and Coulter 2015). Consumers may have hostile attitudes toward the products or brands from the countries that they do not like or want to associate with (Alden et al. 2013). Animosity toward a foreign nation negatively affects the purchase of products produced in that country regardless of the quality judgments (Klein, Ettenson, and Morris 1998). Whereas animosity toward a foreign nation is related to the choices between foreign goods, ethnocentrism is related to choices between domestic and foreign goods (Klein 2002). Even when there are no available domestic brands, the feelings of ethnocentrism, nationalism, and animosity may affect purchase decisions of foreign products (Nijssen and Douglas 2004).

More recently, research has demonstrated that consumer ethnocentrism is a multidimensional construct that includes prosociality, cognition, insecurity, reflexiveness, and habituation. This construct better predicts consumer preferences for local brands at the expense of foreign brands (Siamagka and Balabanis 2015). Researchers have investigated the effect of ethnocentrism by developing a conceptual model that tests the relative influence of consumer ethnocentrism, national identity, and consumer cosmopolitanism on judgment and willingness to purchase domestic and global products (Zeugner-Roth, Zabkar, and Diamantopoulos 2015).

Previous research has also investigated how animosity influences the preferences for the entry-mode choice for the global brands and the postentry branding strategies. 
Specifically, in a high-animosity host country, consumers tend to prefer foreign products that are launched through an acquisition joint venture mode that adopts a local brand or a local-foreign cobrand to one that adopts a foreign-local cobrand (Fong, Lee, and Du 2014). Scholars have further explored the role of ethnicity on global brand beliefs and attitudes (Dimofte, Johansson, and Bagozzi 2010) as well as the role of world mindedness and preference for authenticity on attitude toward local consumer culture positioning, foreign consumer culture positioning, and global consumer culture positioning (Nijssen and Douglas 2011).

Other researchers have used self-verification theory (Westjohn, Singh, and Magnusson 2012) to investigate the effect of global identification on responses to global consumer culture positioning and have used cultural identity theory to demonstrate the relationship between global-local identity beliefs and engagement (Strizhakova, Coulter, and Price 2012). Identity theory was used to develop a scale of global and local identity (Tu, Khare, and Zhang 2012) and demonstrate the relationship between global consumption orientation and attitudes toward global brands from developed and emerging countries (Guo 2013) as well as to identify environmentally friendly tendencies (Strizhakova and Coulter 2013).

\section{CCT}

Since the beginning of 1980s, consumer research has addressed the sociocultural, experiential, symbolic, and ideological aspects of consumption using CCT, because CCT explores the meanings and variety of overlapping cultural groups that exist within the broader framework of globalization (Arnould and Thompson 2015). Research in CCT has mainly investigated the consumer identity projects, marketplace cultures, sociohistoric patterning of consumption (including institutional and social structures that influence consumption), mass-mediated marketplace ideologies, and consumers' interpretive strategies (Hirschman 1993). Given the core focus of CCT research, CCT has been one of the widely used theories to understand the effects of global and local culture.

Consumer culture theory researchers have examined the relative frequency of global consumer culture positioning, foreign consumer culture positioning, and local consumer culture positioning (Alden, Steenkamp, and Batra 1999) as well as effects of local versus nonlocal origin on product attitudes (Batra et al. 2000). Research in this area has mainly focused on changing meanings as a result of globalization (Bengtsson, Bardhi, and Venkatraman 2010). For example, using CCT, research demonstrated the hegemonic influence of Starbucks on the sociocultural milieus of coffee shops
(Thompson and Arsel 2004). Researchers have also investigated global structural commonalities (Kjeldgaard and Askegaard 2006), the effects of perceived brand globalness and global brand authenticity on global brand purchase likelihood (Özsomer and Altaras 2008), the shaping of a transnational imagined community (Cayla and Eckhardt 2008), cultural openness and consumer ethnocentrism on branded product importance (Strizhakova, Coulter, and Price 2008b), and global citizenship (Strizhakova, Coulter, and Price 2011).

While one research stream suggests that culture will never be globalized, other research streams support the idea that global market segments increase as a result of globalization. With the emergence of globalization, researchers used global CCT to investigate the effects of global and local branding (Holt, Quelch, and Taylor 2004). Research in this stream investigated several topics including the effects of materialism, mass media exposure, susceptibility to normative influence, mass migration exposure (Alden, Steenkamp, and Batra 2006), ethnocentrism, antiglobalism, brand globality (Dimofte, Johansson, and Ronkainen 2008), ethnicity, social expressiveness, quality (Dimofte, Johansson, and Bagozzi 2010), values, demographics (Steenkamp and De Jong 2010), consumer cosmopolitanism (Alden et al. 2013), brand trust, brand prestige (Xie, Batra, and Peng 2015), and standardization and localization of advertising campaigns (Pae, Samiee, and Tai 2002) on perceptions, attitudes, and behavioral outcomes related to global and local branding (De Meulenaer, Dens, and De Pelsmacker 2015).

\section{Psycholinguistics}

Language plays an important role in determining consumer perceptions, evaluations, and decisions (Luna and Peracchio 2001). Research in consumer behavior that relies on psycholinguistics has mainly focused on two areas. First, research has focused on the structural features of language (e.g., properties of grammar). In this stream, scholars have examined how language affects cognition (Zhang, Schmitt, and Haley 2003). Second, research has focused on phonological and lexical-semantic features of language. In this stream, scholars explored how phonological or semantic characteristics of brand names influence consumer evaluations. Like previous work on psycholinguistics and consumer behavior, literature on global and local branding has also benefited from similar psycholinguistics theories, with more emphasis given to understanding the role of phonological and lexical-semantic features of language in evaluating global and local brands.

As global brands gain prominence in the marketplace, brand name selection has become an important managerial 
decision. Research examining brand name standardization and adaptation strategies used by consumer goods Fortune 500 companies in China and Hong Kong has shown that the majority of the firms localize their brand names, typically by translating their brand name into the local language (Francis, Lam, and Walls 2002).

In the following sections, we provide an overview of the research on culture and consumer-brand interactions by presenting research findings in line with their different theoretical approaches (see the Web Appendix). More specifically, we discuss the role of culture on consumer-brand interactions that benefited from (1) consumer information processing, (2) self and identity, (3) CCT, and (4) psycholinguistics.

\section{RESEARCH PERSPECTIVE 2: CULTURAL INFLUENCES ON CONSUMER-BRAND INTERACTIONS}

We believe that it is important to present how previous research has identified different dimensions of culture before discussing our synthesis of the literature. The frameworks proposed by Hofstede (1984), Triandis and Gelfand (1998), and Nisbett et al. (2001) have been used extensively to explain how consumers react to and interact with brands in the global marketplace.

Hofstede (1984) categorized country cultures in four groups: individualism versus collectivism (i.e., the extent to which people in a society are integrated into groups), masculinity versus femininity (i.e., the extent to which there is a preference for achievement, assertiveness, and material rewards for success or a preference for cooperation and modesty), power distance (i.e., the extent to which power is distributed unequally), and uncertainty avoidance (i.e., the extent to which society tolerates ambiguity). Extending Hofstede's work, Triandis and Gelfand (1998) distinguished dimensions of collectivism and individualism (i.e., vertical individualism, horizontal individualism, vertical collectivism, and vertical individualism). Vertical individualism indicates the extent of seeing the self as fully autonomous but acknowledging that inequalities exist among individuals. Horizontal individualism is defined as the extent of seeing the self as fully autonomous but believing that equality between individuals is the key. Vertical collectivism is conceptualized as seeing the self as part of a group but recognizing that there are inequalities within that group. Those who are horizontally collectivist are defined as the ones who see the self as part of a group but believe that everyone in the group has equal rights.
Nisbett et al. (2001) focused on the differences in cognitive processes between East Asian and Western cultures. They suggested that East Asians engage in holistic thinking, whereas Westerners tend to be analytical. Holistic thinking is characterized by attending to the context as a whole as opposed to the pieces, engaging in dialectical thinking, and assigning causality to the contextual factors. In contrast, analytical thinking is characterized by attending to the specific attributes of an object detaching it from its context, relying on formal logic, and assigning causality to the actors as opposed to the context.

We suggest that, similar to the literature on global and local branding, the literature on culture and consumer-brand interactions can be divided into three time periods: (1) 1990s, (2) between 2000 and 2010, and (3) from 2010 onward. Reviewing the literature (Figure 2), in the early 1990s, scholars mostly investigated the effect of various brand-related factors such as luxury versus necessity, brand tactics, brand name, packaging, and masculinity versus femininity (Childers and Rao 1992; Dawar and Parker 1994; Pan and Schmitt 1996; Leclerc, Schmitt, and Dubé 1994) on attitudes and behavioral outcomes. In the 2000s, using mostly information processing and psycholinguistic theories, the literature continued to explore different brand-related factors such as brand extensions (Bottomley and Holden 2001), design (Henderson et al. 2003), sensory characteristics (Hong, Pecotich, and Shultz 2002; Madden, Hewett, and Roth 2000; Tavassoli and Han 2002; Zhang and Schmitt 2001), and quality (Erdem, Zhao, and Valenzuela 2004; Miyazaki, Grewal, and Goodstein 2005). Researchers have also investigated marketplace and consumer trends that gained importance during this time, such as online consumer experience (Steenkamp and Geyskens 2006), counterfeiting (Green and Smith 2002), antibrand movement (Holt 2002) and gray market goods (Huang, Lee, and Ho 2004). Using mostly self and identity theories, researchers have further focused on understanding the effects of cultural norms and ideologies (Coulter, Price, and Feick 2003; Eckhardt and Houston 2002) and consumer characteristics (Chan et al. 2009; Erdem, Zhao, and Valenzuela 2004; Strizhakova, Coulter, and Price 2008a; Swaminathan, Page, and Gürhan-Canli 2007) on attitudes, inferences, and behavioral outcomes.

From 2010 through the present, researchers have used self and identity, information processing, and consumer culture theories to investigate the effects of consumer characteristics (Izberk-Bilgin 2012; Pauwels, Erguncu, and Yildirim 2013) on attitudes, inferences, and behavioral outcomes in addition to other brand-related factors such as brand origins (Paharia et al. 2011). Most of the cross-cultural brand 
extension research that used information processing theories also fell into this period (Iversen and Hem 2011; Lane and Fastoso 2016; Monga and John 2007, 2010; Ng 2010; Sichtmann and Diamantopoulos 2013; Torelli and Ahluwalia 2012).

\section{CURRENT LITERATURE ON CULTURE AND CONSUMER-BRAND INTERACTIONS Consumer Information Processing}

An important issue that is related to how brands operate in the global context is the management of brand extensions ( $\mathrm{Ng} 2010)$. A brand extension is the use of an existing brand name in other product categories to capitalize on the brand's favorable associations. Specifically, when the perceived fit between a parent brand and the extension is high, parent brand associations and quality evaluations are likely to transfer to the brand extension. Cross-cultural research on brand extensions has shown that Western consumers perceive fit as highly important, while Eastern consumers consider the company size an important indicator of the quality (Han and Schmitt 1997). Global and local origin associations may also influence the prebrand image. In other words, they may influence the forward spillover effects on the attitudes toward the extensions and the subsequent dilution effects on the postbrand image of the parent brand (Iversen and Hem 2011). When a brand and the extended product category signal the same cultural schema, an automatic activation of cultural schema may override the fit judgment effects, which may result in enhanced extension evaluations (Torelli and Ahluwalia 2012). This effect is explained by people's engagement in more fluent processing when evaluating the culturally congruent versus culturally incongruent or culturally neutral extensions.

Similar differences were found between Westerners and Easterners when consumers switched brands after an unsatisfactory consumption experience $(\mathrm{Ng}, \mathrm{Kim}$, and Rao 2015). Whereas Easterners are more likely to switch brands when the unsatisfactory experience results from an inaction on the part of the group to which they belong (vs. their own inaction), the opposite holds for Westerners. Holistic thinkers tend to provide more favorable responses for functional brands; however, for prestige brands, holistic and analytic thinkers tend to respond equally favorably (Monga and John 2010). Research has also investigated the role of consumer expertise, quality (Bottomley and Holden 2001), and COO effects on international brand name evaluation (Pecotich and Ward 2007); brand extension ad exposure on global brand evaluation (Lane and Fastoso 2016); and comparative affective states on online brand perceptions (Siamagka, Christodoulides, and Michaelidou 2015). These findings suggest that cultural effects play an important role in consumers' perceptions of brand extensions.

Research has also investigated the relationship between risk reduction and brand relevance in category, the interplay of multiple cultural beliefs on luxury brand evaluations (Seo, Buchanan-Oliver, and Cruz 2015) and the growing popularity of brands and purchase likelihood (Dawar and Parker 1994). Further research has examined the effects of communication appeal type (e.g., connected vs. separate) on attitudes toward the brand (Wang et al. 2000), effect of color on attitudes toward logos (Madden, Hewett, and Roth 2000), brand gender perceptions across cultures (Lieven and Hildebrand 2016), and online brands' perceived values (Steenkamp and Geyskens 2006).

\section{Self and Identity}

Research in the self and identity stream has covered a wide range of topics, including the self-concept connection on brand evaluations (Swaminathan, Page, and Gürhan-Canli 2007), the effect of culture on regret ( $\mathrm{Ng}, \mathrm{Kim}$, and Rao 2015), concern for and belief in fate on dissatisfaction (Chan, Wan, and Sin 2009), the effect of cultural orientation on evaluation of luxury brands (Yim et al. 2014), and power distance belief on price and quality perceptions (Lalwani and Forcum 2016).

Other research has investigated the effects of self-brand connection (Eisingerich and Rubera 2010) and values (Limon, Kahle, and Orth 2009; Sung and Tinkham 2005) on the relationship between culture and consumer-brand interactions. Engaging customers with social media is associated with higher brand relationship quality and word of mouth when anthropomorphism and uncertainty avoidance is high (Hudson et al. 2016). Research in this stream has further used brand awareness, price tactics, performance tactics, normative tactics (Leong 1993), power distance, uncertainty avoidance, product category interest, and involvement on information-giving and -seeking behavior (Dawar, Parker, and Price 1996); cultural orientation on consumers' corporate associations (Moon, Lee, and Oh 2015); brand image strategy, modernity, and effect of national culture (Roth 1995); and different cultural elements (e.g., belief in fate, East vs. West, cultural symbolism; Chan et al. 2009) in understanding the effects of culture on consumer-brand interactions. 
Compared with the literature on global and local branding, relatively little research has used CCT to investigate the link between culture and consumer-brand relationships. Researchers have focused on understanding the effects of current branding practices on the antibranding movement (Holt 2002), brand quality perceptions in different cultures (Maxwell 2001), social networks and involvement with branded products (Coulter, Price, and Feick 2003), and brand mythology on branding in the global marketplace (Cayla and Arnould 2008). Some research has also investigated country differences in consumers' attitudes toward advertisements and advertisement appeals (Liu, Cheng, and Li 2009; Okazaki, Mueller, and Taylor 2010), CSR programs (Becker-Olsen et al. 2011), and brand recognition and price perceptions (Kustin 1993).

\section{Psycholinguistics}

Research investigating the role of language, culture, and branding relies on theories from psycholinguistics. Early research has shown that French pronunciation of a brand name affects the perceived hedonism of the products and attitudes toward the brand; however, when the COO information is added to the French branding, the effect diminishes (Leclerc, Schmitt, and Dubé 1994). However, the translation effect depends not only on linguistic factors but also on how well the brand is known in the marketplace (Hong, Pecotich, and Shultz 2002). French-, Spanish-, and Chinese-speaking individuals prefer brand names in which there is a match between the phonetic symbolism of the words and the product attributes (Shrum et al. 2012). Similarly, research has also shown that native English-speakers prefer front vowels regardless of car type, but they prefer plosives in the international brand names of sport utility vehicles (Kuehnl and Mantau 2013). Finally, although most of the research in this stream has focused on the English name creation for global brands, Zhang and Schmitt (2001) provided a conceptual framework that incorporated a linguistic analysis of three translation methods (i.e., phonetic, semantic, and phonosemantic) and a cognitive analysis that focused on the effect of primes and expectations on consumer name evaluations. In summary, previous research has extensively investigated brand name decisions in the global marketplace because they have important consequences for brands that operate in a global context. Other research has explored the effects of language on memory for brands (Schmitt, Pan, and Tavassoli 1994), masculine versus feminine scripts on attitude toward the brand (Pan and Schmitt 1996), auditory versus visual brand identifiers on memory (Tavassoli and Han 2002), and the standardization versus adaptation processes of brand visuals (Jordá-Albiñana et al. 2009).
Research on global and local branding and cross-cultural differences in consumer-brand relationships has widely used information processing, self and identity, CCT, and psycholinguistics to understand consumer attitudes and beliefs toward global and local brands. Despite extensive research efforts and progress, we identify some gaps that future research might fill. We also highlight additional theoretical frameworks (i.e., affect, mood, emotions, and motivation theories) that could be applied and extended in this domain.

\section{Consumer Information Processing}

Research in information processing has investigated the different stages of information processing (attention, encoding and comprehension, inference, and response processes). Although previous literature has focused mainly on encoding and the comprehension processes of information processing, there is gap in the literature regarding why consumers pay differing amounts of attention to the various aspects of global and local brands. We suggest that, on the one hand, global brands may be perceived at the global level, and thus, any information related to them may be processed abstractly, which in turn may lead people to pay attention to the desirability features (e.g., higher-order goals). On the other hand, local brands may be perceived as subsets of global brands and thus may be processed concretely, which in turn may lead people to pay attention to the feasibility features (e.g., lowerorder specific features of the brand). Relatedly, if our proposition that global (local) brands are processed abstractly (concretely) holds true, consumers may pay attention to more detailed features of local brands compared with global brands.

Because consumers are continuously exposed to a diverse range of information about global and local brands, future research might investigate the extent to which fluency and mere exposure effects may underlie consumers' reactions to global versus local brands. Research on fluency effects has suggested that fluency increases confidence for people who process information at lower construal levels but decreases confidence for people who process information at higher construal levels. We suggest that fluency might have a positive influence on consumer confidence in the evaluations of local brands but a negative influence on consumer confidence in evaluations of global brands, which implies that fluency effects might backfire for the global brands. In addition, research in this stream lacks empirical investigations about the role of consumer learning and expertise in evaluating global and local brands. 


\section{Self and Identity}

Recent research has suggested five principles that might help scholars model the process of identity formation and expression (Reed et al. 2012). Specifically, identity salience, identity association, identity relevance, identity verification, and identity conflict determine the influence of identity on consumer behavior. Building on previous literature, future research can address how different aspects of identity formation and expression may influence evaluations of global and local brands.

With the increasing number of expatriates and immigrants around the world, an area worth investigating is how the activation of a national, global, or cosmopolitan identity may influence the evaluations of global and local brands. Research has suggested that identity salience exists when a certain identity is accessible to a consumer. Future research could investigate how global and local brands might activate different identities. We propose that when consumers evaluate global and local brands, different identities for the same consumer might be salient. For example, whereas a more cosmopolitan identity might influence the preferences of a consumer who is exposed to a global brand, the same consumer might behave in accordance with what is expected from his or her culture when exposed to a local brand.

Research can also explore the role of identity association and identity relevance on the evaluation of or preference for global and local brands. Whether and when consumers associate themselves with global or local brands could be examined further.

\section{CCT}

As discussed previously, research in CCT has mainly investigated consumer identity projects, marketplace cultures, sociohistoric patterning of consumption (including institutional and social structures that influence consumption), massmediated marketplace ideologies, and consumers' interpretive strategies. Scholars in CCT read texts (e.g., advertisements) as information that conveys consumers' lifestyles and identities (Arnould and Thompson 2015). In a globalized world with fast-paced information technologies, consumers are able to communicate with each other and with companies on digital platforms. What might these communications reveal about consumers' real or desired identities? Research in CCT might benefit from analyzing these texts to understand how consumers give meaning to global and local brands. One context that might benefit from the application of CCT is Twitter. Millions of consumers use Twitter to communicate with each other and with brands. Although there is a growing interest in understanding how consumers communicate using Twitter, there is still gap in the literature regarding how consumers form groups on social media and how these groups influence brand evaluations. For example, with the growing political polarization in the West, many consumers are involved in groups on social media to protest certain global or local brands. By analyzing the discussions on blogs or social media (e.g., Twitter), future research might investigate whether this group influence is more pronounced for global or local brands. We propose that the influence of groups on boycotting brands could be higher for global (vs. local) brands because many consumers are then defecting to their local brands.

Furthermore, with the flow of immigration in different parts of the world, diverse social classes are emerging. Although prior research in CCT has investigated how social structures influence consumption, research on global and local branding might benefit from CCT to further understand how the emerging social classes perceive and evaluate these brands.

\section{Psycholinguistics}

Previous research in psycholinguistics has discussed the effects of the structural features of language (e.g., properties of grammar) as well as the phonological and lexicalsemantic features of language. In today's digital environment, brands often communicate with their customers and with each other on social media. Literature is limited in terms of how these communications by global and local brands are perceived on social media across different cultures. Using application programming interface, scholars can collect information from social media platforms on real time to understand how consumers communicate about global or local brands. For example, future research might investigate whether consumers use more first-person or third-person pronouns when they talk about global or local brands. We suggest that because consumers might construe local brands at a lower level, they might use more firstperson pronouns when they communicate information about local brands but more third-person pronouns when they communicate information about global brands, because they might perceive global brands as more distant. Future research can address these issues applying theoretical frameworks in phonological, lexical-semantic, and structural features of language.

\section{Affect, Mood, and Emotion}

Previous research on consumer behavior has investigated the role of affect in thinking, problem solving, and decision making. However, relatively limited research has focused 
on affective processes used in evaluating global and local brands. Amid rising geopolitical tensions and growing polarization within countries, the topic of affective processes that underlie consumer responses to global and local brands warrants further investigation. Similarly, how brands position themselves in a polarized world, particularly in relation to addressing inequalities in different parts of the world, is important to understand from a global and local branding perspective. Because affect influences consumer responses significantly, the influence of polarization on the possibility of extreme affective reactions toward brands and companies is another topic of interest. Corporate social responsibility positioning also influences affective responses (Yoon, Gürhan-Canli, and Schwarz 2006). Future research might investigate how CSR activities influence affective responses toward global and local brands differently.

Brand love and brand hate are important outcomes of consumer-brand interactions. Research has shown that brand love is an antecedent to brand loyalty, and satisfaction is an antecedent to brand love (Carroll and Ahuvia 2006). How culture influences brand love for global and local brands is a topic of interest that future research could investigate. Similarly, brand hate results from dissatisfaction with the brand. Determining under which conditions consumers demonstrate this strong negative affective response to global versus local brands will further help shed light on the role of affect in global branding.

\section{Motivation}

Although previous research in marketing has extensively investigated the role of motivation on consumer behavior, it is surprising that neither literature on global and local branding nor literature on culture and consumer-brand interactions has investigated the role of motivation deeply. Goal pursuit is an important research area because individual behavior is mostly goal directed (Bagozzi and Dholakia 1999). We suggest that further research can explore how consumers from different cultures set their goals, how consumers with different ideological positions pursue their goals, and how consumers perceive global and local brands in addressing their goal pursuits.

\section{WHAT LIES AHEAD AND FUTURE RESEARCH DIRECTIONS IN PRACTICE}

Whether globalization continues or whether it is nearing an end has been a topic of discussion for the past several years. Regardless of its pace, it seems that investigating the role of culture and brands in the global context will always be popular among researchers and practitioners. In this section, we discuss the recent changes arising from the realities of the twenty-first century and suggest future research avenues for scholars to pursue in global branding. Table 1 summarizes research opportunities in practice and propositions.

The topics of discussion at the 2016 Annual Meeting of the World Economic Forum in Davos, Switzerland, ranged from terrorist attacks and recessions to the recent focus on radical global changes (Laudicina 2016). The world is in a constant state of evolution, revolution, and transformation. This reality was reflected in the session title vocabulary at the 2016 Davos meeting. According to a report released by The Global Business Policy Council at A.T. Kearney, globalization may continue its pace because of greater connectivity enabled by technological advances (i.e., the return to the high economic growth and trade of the early 2000s with improvements in information and communication technologies and low commodity prices).

Consumers are more empowered than ever in their interaction with brands and companies (Erdem et al. 2016). Consumer-brand relationships have moved to online platforms where consumers are continuously posting, sharing, and seeking others' opinions. Content moves across borders at the click of a button. While the digital transformation enables brands to communicate with their consumers in a much faster and interactive manner on a global scale, it leads to concerns such as growing cyber insecurity, privacy concerns, and the prevalence of unsubstantiated digital content. These increasingly important topics have not been fully explored in the current literature on cross-cultural differences in consumer-brand relationships. Future studies might investigate the role of fake user accounts on disseminating information across borders. Research has shown that consumers rely on negative information when information load is low. We suggest that because information load might be lower for local brands than for global brands, the influence of negative reviews by fake accounts might have more negative impact for local brands than global brands.

Targeted marketing is on the rise (Tucker 2014). Technology is making it easier for brands to personalize their offers and messages. Given that marketing is moving to computermediated environments (Yadav and Pavlou 2014), further research needs to investigate how global consumer culture evolves in this digital world without boundaries. Are there cultural differences in the way consumers interact with brands on social media? Does digital content vary as a function of culture? Are there distinctions between global and local brands in terms of their presence in the digital 
Table 1. Future Research Opportunities in Practice and Propositions

\begin{tabular}{l}
\hline Topic \\
\hline Digitalization \\
printing) in their interaction with brands? Does digital content about brands vary as a function of \\
culture? \\
- Is there a distinction between a global and a local brand in terms of their presence in the digital \\
domain? \\
- Are there cultural differences in the way consumers interact with brands in different platforms on \\
social media? \\
- What is the role of new sources of information (e.g., bloggers, YouTubers) for consumers learning \\
about brands? Do the processes change as a function of culture? \\
- Are there cross-cultural differences in the way consumers respond to the increasing levels of targeted \\
marketing and brand interactivity? \\
- Does online donation behavior differ between collectivist and individualist cultures? \\
- What does it mean to be a global brand when any company can potentially reach consumers globally \\
using social media? What new measures can be constructed to test the influence of technology on \\
global branding?
\end{tabular}

Polarization

Political issues

Macro issues

- Amid rising geopolitical tensions and growing polarization within different countries, what type of affective processes might underlie consumer responses to global versus local brands?

- How do brands position themselves in a polarized world, particularly when addressing inequalities in different parts of the world? Would polarization lead to extreme affective reactions toward brands and companies? Specifically, how would CSR positioning influence affective responses?

- How does culture influence polarized worldviews across consumer segments? To what extent does consumer activism relate to polarization and tension across the globe?

- How are consumers in different cultures changing their relationships with global and local brands in increasingly nationalist political climates (e.g., Brexit)? How might brands be influenced by these populist movements?

- How does political ideology affect cross-cultural consumer behavior and consumer reactions to global and local brands?

- Which values have changed in specific cultures as a result of global macro change? If there are shifting values and sentiments, how does this affect consumer goal pursuit and behavior in the marketplace?

- How do consumers perceive the role of brands in addressing social and environmental concerns? Do consumers differ in their expectations and tolerance levels toward local and global brand practices? What are cross-cultural differences and similarities that underlie consumers' new sensitivity concerning the environment and social issues?

- What is the meaning of brands in the context of sharing and localization? How do different dimensions of culture influence attitudes toward sharing and localization?

environment? Are there cross-cultural differences in the way consumers respond to the increasing levels of targeted marketing and brand interactivity? What does it mean to be a global brand when any company can potentially reach consumers globally using social media such as Twitter or Facebook? What is the role of new sources of information (e.g., bloggers, YouTubers) for consumers learning about brands? What new measures can be constructed to test the influence of technology on global branding? Many donation campaigns are run on digital applications. In some of these campaigns, consumers can donate either individually or in teams. Future research might investigate whether, for global 
donation campaigns, people from individualist cultures tend to use the individual donation functions and people from collectivist cultures use the team donation functions. We suggest that because all consumers belong to the same culture in the digital environment, donations using individual donation functions might be more prevalent than donations using team functions because consumers might not feel the need to belong to a group. In investigating these topics, use of social media and digital data will especially be useful.

The rise of nationalism in major economies and increased barriers to trade may pause or reverse globalization trends (Laudicina and Peterson 2016). Future research might focus on understanding how consumers in different cultures are changing their relationships with global and local brands in the current political climate exemplified by Brexit and the discussion of building a border wall between the United States and Mexico. Similarly, there are independence movements (e.g., the Spanish region of Catalonia) all around the world. For example, Barcelona is a global brand that is known for its success in sports, especially in football and basketball. If Catalonia separates from Spain, how would the perceptions for Barcelona change in the eyes of consumers? We suggest that although many consumers would still perceive Barcelona as a global brand, consumers would also begin to place importance on the local features of Barcelona. Thus, the distinction between a global and a local brand might become blurred with more considerations for the local features of the brands that were once called global. How are brands influenced by these populist movements? How does political ideology affect cross-cultural consumer behavior and consumer reactions to global and local brands?

In the increasingly competitive global environment, culture is a dynamic force for change rather than a rigid set of forms and rules. As the World Commission on Culture and Development has noted, a society's culture is in a constant state of flux that influences and is being influenced by other views. With the globalization trend of the past several decades, there has been an extensive integration of societies. Increasing immigration and multiculturalism lead to greater cultural diversity. However, this trend also may have led to the loss of the uniqueness of local cultures (Fu and Chiu 2007). Which values were lost, how this loss of values influenced behavior in the marketplace, and whether there are certain sets of values that are untouchable for some cultures are some areas of research that may yield further insight into the topic.

Although previous research has mainly focused on globalization and localization, hybridization has recently gained importance. Hybridization is not merely mixing and synthesizing different elements of cultures; instead, it is the generation of new cultures and new interpersonal connections. For example, the Disney character Mulan (from the 1998 animated movie of the same name), based on a legendary Chinese figure, is an example of the acculturalization, reculturalization, and deculturalization that occurs in the hybridization of cultural products.

Consumers around the world are becoming more environmentally conscious and expect brands to behave responsibly (Kotler 2011). Environmental problems such as global climate change, shrinking natural resources, and rising sea levels have led more brands to employ practices against climate change (e.g., IKEA, General Motors, Nike). The concerns about increasing pollution levels have resulted in more sustainable innovations (e.g., Tesla electric cars). In addition, some brands and businesses benefit low-income communities (e.g., Unilever has created jobs in emerging markets). Brands are also responding to critical social justice and human rights issues in the global marketing environment (e.g., Starbucks, Converse and Kiehl's supported the gay rights movement by introducing products and promotions that aid LGBT charities financially; Pesce 2017). Many brands address inequality in their marketing campaigns (e.g., top U.S. brands supporting the 100,000 Opportunities Initiative to support a young workforce [https:// www.100kopportunities.org]). Consumers expect brands to be more transparent and to do more good, and they punish brands that do wrong (e.g., the recent Volkswagen emission crisis). These issues may influence consumers' relationships with brands differently across cultures. Consumers may differ in their expectations and level of tolerance toward brand practices at home or abroad. Because companies operate across a much broader geographic phase, we need a better understanding of the crosscultural differences and similarities that underlie consumers' new sensitivities. Further research can examine how global and local brands can find their points of parity and points of difference to convey prominent brand attributes (i.e., innovativeness, responsiveness, and responsibility) to consumers in a global context (Gürhan-Canli, Hayran, and Sarial-Abi 2016).

Finally, while most academic brand research has been conducted in more developed regions of the world (e.g., the United States, Europe), scholars and managers need more cross-cultural analyses in regions such as the Middle East and Africa to understand the differences in consumers' perceptions and adoption of global brands. How globalization affects marketplace dynamics and consumer behavior in less industrialized countries provides promising avenues for further research. 
Collectively, we believe that these research efforts will advance our knowledge on consumer-brand relationships across the globe.

\section{LIMITATIONS AND CONCLUSION}

This research aims to contribute to the analyses of the growing body of research on global branding (e.g., Chabowski, Samiee, and Hult 2013; Özsomer and Altaras 2008; Whitelock and Fastoso 2007) by organizing and synthesizing the existing findings in literature. Our article differs from and complements previous important syntheses in the field (e.g., Chabowski, Samiee, and Hult 2013; Özsomer and Altaras 2008; Whitelock and Fastoso 2007) by specifically focusing on the behavioral outcomes of consumer-brand relationships in the global environment.

It is important to highlight again that, as with all literature reviews, our review does not capture all the articles that have been published in this research stream. For brevity, our research has a limited focus on articles that have been published between 1992 and 2016 in the major marketing outlets. Furthermore, we limited our focus to research that examined consumer responses, and we did not incorporate research with a strategy focus in our analyses. A more extended review could cover articles from a wider selection of academic journals and those that elaborated on a broader set of dependent variables (e.g., firm-related outcomes).

Our research is descriptive in nature. We tried to organize the current literature under themes. After reviewing all the articles, we identified two research perspectives (i.e., global-local branding and the influence of culture on consumer-brand interactions). However, some articles may have overlapping concepts from both research perspectives, since they explore multiple variables. Without doubt, global and local branding research is influenced by existing cross-cultural research. We aimed to allocate each article under the predominant research perspective according to the independent and dependent variables explored in them.

Our review demonstrates that previous literature mainly used information processing, self and identity, CCT, and psycholinguistics to investigate the relationship between culture, brands, and consumers. While we chose to organize the existing literature by the theoretical focus of articles, an alternative approach could be to provide a research synthesis based on topics investigated. This alternative structuring could yield more subsections and, thus, a more detailed elaboration on various topics analyzed in the literature.
Overall, we believe that an integrative review of research on global branding, culture, and consumer behavior is timely and important from both theoretical and managerial perspectives. We intend to fill different gaps in the literature and provide a fruitful future research agenda in terms of incorporating recent worldwide trends such as the increasing level of digitalization, sustainability developments, and changing political conditions. We address a range of research questions that will advance our knowledge on consumer-brand relationships in response to recent global macro changes. We hope that scholars will benefit from the ideas presented in this study in their future research.

\section{REFERENCES}

Alden, Dana L., James B. Kelley, Petra Riefler, Julie A. Lee, and Geoffrey N. Soutar (2013), "The Effect of Global Company Animosity on Global Brand Attitudes in Emerging and Developed Markets: Does Perceived Value Matter?” Journal of International Marketing, 21 (2), 17-38.

Alden, Dana L., Jan-Benedict E.M. Steenkamp, and Rajeev Batra (1999), "Brand Positioning Through Advertising in Asia, North America, and Europe: The Role of Global Consumer Culture," Journal of Marketing, 63 (1), 75-87.

Alden, Dana L., Jan-Benedict E.M. Steenkamp, and Rajeev Batra (2006), "Consumer Attitudes Toward Marketplace Globalization: Structure, Antecedents and Consequences," International Journal of Research in Marketing, 23 (3), 227-39.

Allman, Helena F., Anton P. Fenik, Kelly Hewett, and Felicia N. Morgan (2016), "Brand Image Evaluations: The Interactive Roles of Country of Manufacture, Brand Concept, and Vertical Line Extension Type," Journal of International Marketing, 24 (2), 40-61.

Arnould, Eric J., and Craig J. Thompson (2015), "Introduction: Consumer Culture Theory: Ten Years Gone (and Beyond)," in Consumer Culture Theory, Anastasia E. Thyroff, Jeff B. Murray, and Russell W. Belk, eds. Bingley, UK: Emerald Group Publishing Limited, 1-21.

Bagozzi, Richard P., and Utpal Dholakia (1999), "Goal Setting and Goal Striving in Consumer Behavior," Journal of Marketing, 63 (4), 19-32.

Balabanis, George, and Adamantios Diamantopoulos (2011), "Gains and Losses from the Misperception of Brand Origin: The Role of Brand Strength and Country-of-Origin Image," Journal of International Marketing, 19 (2), 95-116.

Batra, Rajeev, Venkatram Ramaswamy, Dana L. Alden, JanBenedict E.M. Steenkamp, and S. Ramachander (2000), "Effects of Brand Local and Non-Local Origin on Consumer 
Attitudes in Developing Countries," Journal of Consumer Psychology, 13 (9), 83-95.

Becker-Olsen, Karen L., Charles R. Taylor, Ronald Paul Hill, and Goksel Yalcinkaya (2011), "A Cross-Cultural Examination of Corporate Social Responsibility Marketing Communications in Mexico and the United States: Strategies for Global Brands," Journal of International Marketing, 19 (2), 30-44.

Bengtsson, Anders, Fleura Bardhi, and Meera Venkatraman (2010), "How Global Brands Travel with Consumers: An Examination of the Relationship Between Brand Consistency and Meaning Across National Boundaries," International Marketing Review, 27 (5), 519-40.

Bottomley, Paul A., and Stephen J.S. Holden (2001), "Do We Really Know How Consumers Evaluate Brand Extensions? Empirical Generalizations Based on Secondary Analysis of Eight Studies," Journal of Marketing Research, 38 (4), 494-500.

Carroll, Barbara A., and Aaron C. Ahuvia (2006), "Some Antecedents and Outcomes of Brand Love," Marketing Letters, 17 (2), 79-89.

Cayla, Julien, and Giana M. Eckhardt (2008), "Asian Brands and the Shaping of a Transnational Imagined Community," Journal of Consumer Research, 35 (2), 216-30.

Cayla, Julien, and Eric J. Arnould (2008), "A Cultural Approach to Branding in the Global Marketplace," Journal of International Marketing, 16 (4), 86-112.

Chabowski, Brian R., Saeed Samiee, and G. Tomas M. Hult (2013), "A Bibliometric Analysis of the Global Branding Literature and a Research Agenda," Journal of International Business Studies, 44 (6), 622-34.

Chan, Haksin, Lisa C. Wan, and Leo Y. Sin (2009), "The Contrasting Effects of Culture on Consumer Tolerance: Interpersonal Face and Impersonal Fate," Journal of Consumer Research, 36 (2), 292-304.

Childers, Terry L., and Akshay R. Rao (1992), "The Influence of Familial and Peer-Based Reference Groups on Consumer Decisions," Journal of Consumer Research, 19 (2), 198-211.

Coulter, Robin A., Linda L. Price, and Lawrence Feick (2003), "Rethinking the Origins of Involvement and Brand Commitment: Insights from Postsocialist Central Europe," Journal of Consumer Research, 30 (2), 151-69.

Davvetas, Vasileios, and Adamantios Diamantopoulos (2016), "How Product Category Shapes Preferences Toward Global and Local Brands: A Schema Theory Perspective," Journal of International Marketing, 24 (4), 61-81.

Davvetas, Vasileios, Christina Sichtmann, and Adamantios Diamantopoulos (2015), "The Impact of Perceived Brand
Globalness on Consumers' Willingness to Pay," International Journal of Research in Marketing, 32 (4), 431-34.

Dawar, Niraj, and Philip Parker (1994), “Marketing Universals: Consumers' Use of Brand Name, Price, Physical Appearance, and Retailer Reputation as Signals of Product Quality," Journal of Marketing, 58 (2), 81-95.

Dawar, Niraj, Phillip M. Parker, and Lydia J. Price (1996), "A Cross-Cultural Study of Interpersonal Information Exchange," Journal of International Business Studies, 27 (3), 497-516.

De Meulenaer, Sarah, Nathalie Dens, and Patrick De Pelsmacker (2015), "Which Cues Cause Consumers to Perceive Brands as More Global? A Conjoint Analysis," International Marketing Review, 32 (6), 606-26.

Dimofte, Claudiu V., Johny K. Johansson, and Richard P. Bagozzi (2010), "Global Brands in the United States: How Consumer Ethnicity Mediates the Global Brand Effect," Journal of International Marketing, 18 (3), 81-106.

Dimofte, Claudiu V., Johny K. Johansson, and Ilkka A. Ronkainen (2008), "Cognitive and Affective Reactions of US Consumers to Global Brands," Journal of International Marketing, 16 (4), 113-35.

Eckhardt, Giana M., and Michael J. Houston (2002), "Cultural Paradoxes Reflected in Brand Meaning: McDonald's in Shanghai, China," Journal of International Marketing, 10 (2), 68-82.

Eisingerich, Andreas, and Gaia Rubera (2010), "Drivers of Brand Commitment: A Cross-National Investigation," Journal of International Marketing, 18 (2), 64-79.

Erdem, Tülin, Kevin Lane Keller, Dmitri Kuksov, and Rik Pieters (2016), "Understanding Branding in a Digitally Empowered World," International Journal of Research in Marketing, 1 (33), 3-10.

Erdem, Tülin, Ying Zhao, and Ana Valenzuela (2004), "Performance of Store Brands: A Cross-Country Analysis of Consumer Store-Brand Preferences, Perceptions, and Risk," Journal of Marketing Research, 41 (1), 86-100.

Fischer, Marc, Franziska Völckner, and Henrik Sattler (2010), "How Important Are Brands? A Cross-Category, CrossCountry Study," Journal of Marketing Research, 47 (5), 823-39.

Fong, Cher-Min, Chun-Ling Lee, and Yunzhou Du (2014), "Consumer Animosity, Country of Origin, and Foreign EntryMode Choice: a Cross-Country Investigation," Journal of International Marketing, 22 (1), 62-76.

Francis, June N.P., Jan Lam, and Janet Walls (2002), “The Impact of Linguistic Differences on International Brand Name Standardization: A Comparison of English and Chinese Brand 
Names of Fortune-500 Companies," Journal of International Marketing, 10 (1), 98-116.

Fu, Jeanne Ho-Ying, and Chi-Yue Chiu (2007), "Local Culture's Responses to Globalization: Exemplary Persons and Their Attendant Values," Journal of Cross-Cultural Psychology, 38 (5), 636-53.

Funk, Charles A., Jonathan D. Arthurs, Len J. Treviño, and Jeff Joireman (2010), "Consumer Animosity in the Global Value Chain: The Effect of International Production Shifts on Willingness to Purchase Hybrid Products," Journal of International Business Studies, 41 (4), 639-51.

Gineikiene, Justina, Boda B. Schlegelmilch, and Ruta Ruzeviciute (2016), "Our Apples Are Healthier Than Your Apples: Deciphering the Healthiness Bias for Domestic and Foreign Products," Journal of International Marketing, 24 (2), 80-99.

Green, Robert T., and Tasman Smith (2002), "Executive Insights: Countering Brand Counterfeiters," Journal of International Marketing, 10 (4), 89-106.

Guo, Xi (2013), "Living in a Global World: Influence of Consumer Global Orientation on Attitudes Toward Global Brands from Developed Versus Emerging Countries," Journal of International Marketing, 21 (1), 1-22.

Gürhan-Canli, Zeynep, Ceren Hayran, and Gülen Sarial-Abi (2016), "Customer-Based Brand Equity in a Technologically Fast-Paced, Connected, and Constrained Environment," Academy of Marketing Science Review, 6 (1), 23-32.

Han, Jin K., and Bernd H. Schmitt (1997), "Product-Category Dynamics and Corporate Identity in Brand Extensions: A Comparison of Hong Kong and U.S. Consumers," Journal of International Marketing, 5 (1), 77-92.

Harmeling, Colleen M., Peter Magnusson, and Nitish Singh (2015), "Beyond Anger: A Deeper Look at Consumer Animosity," Journal of International Business Studies, 46 (6), 676-93.

Häubl, Gerald, and Terry Elrod (1999), “The Impact of Congruity Between Brand Name and Country of Production on Consumers' Product Quality Judgments," International Journal of Research in Marketing, 16 (3), 199-215.

Heinberg, Martin, H. Erkan Ozkaya, and Markus Taube (2016), "A Brand Built on Sand: Is Acquiring a Local Brand in an Emerging Market an Ill-Advised Strategy for Foreign Companies?" Journal of the Academy of Marketing Science, 44 (5), 586-607.

Henderson, Pamela W., Joseph A. Cote, Siew Meng Leong, and Bernd Schmitt (2003), "Building Strong Brands in Asia: Selecting the Visual Components of Image to Maximize Brand Strength," International Journal of Research in Marketing, 20, 297-313.
Herz, Marc F., and Adamantios Diamantopoulos (2013), "Country-Specific Associations Made by Consumers: A DualCoding Theory Perspective," Journal of International Marketing, 21 (3), 95-121.

Hirschman, Elizabeth C. (1993), "Ideology in Consumer Research, 1980 and 1990: A Marxist and Feminist Critique," Journal of Consumer Research, 19 (4), 537-55.

Hofstede, Geert H. (1984), Culture's Consequences: International Differences in Work-Related Values. Beverly Hills, CA: Sage Publications.

Holt, Douglas B. (2002), "Why Do Brands Cause Trouble? A Dialectical Theory of Consumer Culture and Branding," Journal of Consumer Research, 29 (1), 70-90.

Holt, Douglas B., John A. Quelch, and Earl L. Taylor (2004), "How Global Brands Compete," Harvard Business Review, $82(9), 68-75$.

Hong, F.C. (Frank), Anthony Pecotich, and Clifford J. Shultz (2002), "Brand Name Translation: Language Constraints, Product Attributes, and Consumer Perceptions in East and Southeast Asia," Journal of International Marketing, 10 (2), 29-45.

Hsieh, Ming-Huei (2002), "Identifying Brand Image Dimensionality and Measuring the Degree of Brand Globalization: A Cross-National Study," Journal of International Marketing, 10 (2), 46-67.

Hsieh, Ming-Huei (2004), "Measuring Global Brand Equity Using Cross-National Survey Data," Journal of International Marketing, 12 (2), 28-57.

Hsieh, Ming-Huei, Shan-Ling Pan, and Rudy Setiono (2004), "Product-, Corporate-, and Country-Image Dimensions and Purchase Behavior: A Multicountry Analysis," Journal of the Academy of Marketing Science, 32 (3), 251-70.

Huang, Jen-Hung, Bruce C.Y. Lee, and Shu Hsun Ho (2004), "Consumer Attitude Toward Gray Market Goods," International Marketing Review, 21 (6), 598-614.

Hudson, Simon, Li Huang, Martin S. Roth, and Thomas J. Madden (2016), "The Influence of Social Media Interactions on Consumer-Brand Relationships: A Three-Country Study on Brand Perceptions and Marketing Behaviors," International Journal of Research in Marketing, 33 (1), 27-41.

Iversen, Nina M., and Leif E. Hem (2011), "Reciprocal Transfer Effects for Brand Extensions of Global or Local Origin: Evidence from Norway," International Marketing Review, 28 (4), 365-411.

Izberk-Bilgin, Elif (2012), “Infidel Brands: Unveiling Alternative Meanings of Global Brands at the Nexus of Globalization, 
Consumer Culture, and Islamism," Journal of Consumer Research, 39 (4), 663-87.

Jordá-Albiñana, Begona, Olga Ampuero-Canellas, Natalia Vila, and José Ignacio Rojas-Sola (2009), "Brand Identity Documentation: A Cross-national Examination of Identity Standards Manuals," International Marketing Review, 26 (2), 172-97.

Kjeldgaard, Dannie, and Soren Askegaard (2006), “The Glocalization of Youth Culture: The Global Youth Segment as Structures of Common Difference," Journal of Consumer Research, 33 (2), 231-47.

Klein, Jill G. (2002), “Us Versus Them, or Us Versus Everyone? Delineating Consumer Aversion to Foreign Goods," Journal of International Business Studies, 33 (2), 345-63.

Klein, Jill Gabrielle, Richard Ettenson, and Marlene D. Morris (1998), "The Animosity Model of Foreign Product Purchase: An Empirical Test in the People's Republic of China," Journal of Marketing, 62 (1), 89-100.

Koschate-Fischer, Nicole, Adamantios Diamantopoulos, and Katharina Oldenkotte (2012), “Are Customers Really Willing to Pay for a Favorable Country Image? A Study of Country-ofOrigin Effects on Willingness to Pay," Journal of International Marketing, 20 (1), 19-41.

Kotler, Philip (2011), "Reinventing Marketing to Manage the Environmental Imperative," Journal of Marketing, 75 (4), 132-35.

Kuehnl, Christina, and Alexandra Mantau (2013), "Same Sound, Same Preference? Investigating Sound Symbolism Effects in International Brand Names," International Journal of Research in Marketing, 30 (4), 417-20.

Kustin, Richard Alan (1993), "A Cross-Cultural Study of a Global Product in Israel and Australia," International Marketing Review, 10 (5), 4-13.

Lalwani, Ashok K., and Lura Forcum (2016), "Does a Dollar Get You a Dollar's Worth of Merchandise? The Impact of Power Distance Belief on Price-Quality Judgments," Journal of Consumer Research, 43 (2), 317-33.

Lane, Vicki R., and Fernando Fastoso (2016), “The Impact of Repeated Ad Exposure on Spillover from Low Fit Extensions to a Global Brand," International Marketing Review, 33 (2), 298-318.

Laudicina, Paul (2016), "Davos 2016: Questions About Globalization's End and What Comes Next," Forbes (January 19), https://www.forbes.com/sites/paullaudicina/2016/01/19/ davos-2016-questions-about-globalizations-end-and-what-comesnext/\#202722a419f1.

Laudicina, Paul, and Erik Peterson (2016), "From Globalization to Islandization,” research report, A.T. Kearney Global Business Policy Council, https://www.atkearney.com/web/globalbusiness-policy-council/article?/a/from-globalization-to-islandization.
Leclerc, France, Bernd H. Schmitt, and Laurette Dubé (1994), "Foreign Branding and Its Effects on Product Perceptions and Attitudes," Journal of Marketing Research, 31 (2), 263-70.

Lehmann, Donald R., Kevin Lane Keller, and John U. Farley (2008), "The Structure of Survey-Based Brand Metrics," Journal of International Marketing, 16 (4), 29-56.

Leong, Siew Meng (1993), "Consumer Decision Making for Common, Repeat-Purchase Products: A Dual Replication," Journal of Consumer Psychology, 2 (2), 193-208.

Lieven, Theo, and Christian Hildebrand (2016), “The Impact of Brand Gender on Brand Equity: Findings from a Large-Scale Cross-Cultural Study in Ten Countries," International Marketing Review, 33 (2), 178-95.

Limon, Yonca, Lynn R. Kahle, and Ulrich R. Orth (2009), "Package Design as a Communications Vehicle in CrossCultural Values Shopping," Journal of International Marketing, 17 (1), 30-57.

Lin, Chih-Pin, and Cheng-Min Chuang (2016), "Corruption and Brand Value," International Marketing Review, 33 (6), 758-80.

Liu, Fang, Hong Cheng, and Jianyao Li (2009), "Consumer Responses to Sex Appeal Advertising: A Cross-Cultural Study," International Marketing Review, 26 (4/5), 501-20.

Luna, David, and Laura A. Peracchio (2001), "Moderators of Language Effects in Advertising to Bilinguals: A Psycholinguistic Approach," Journal of Consumer Research, 28, 284-95.

Madden, Thomas J., Kelly Hewett, and Martin S. Roth (2000), "Managing Images in Different Cultures: A Cross-National Study of Color Meanings and Preferences," Journal of International Marketing, 8 (4), 90-107.

Madden, Thomas J., Martin S. Roth, and William R. Dillon (2012), "Global Product Quality and Corporate Social Responsibility Perceptions: A Cross-National Study of Halo Effects," Journal of International Marketing, 20 (1), 42-57.

Martín, Oscar, and Julio Cerviño (2011), “Towards an Integrative Framework of Brand Country of Origin Recognition Determinants: A Cross-Classified Hierarchical Model," International Marketing Review, 28 (6), 530-58.

Maxwell, Sarah (2001), "An Expanded Price/Brand Effect Model: A Demonstration of Heterogeneity in Global Consumption," International Marketing Review, 18 (3), 325-43.

Melnyk, Valentyna, Kristina Klein, and Franziska Völckner (2012), "The Double-Edged Sword of Foreign Brand Names for Companies from Emerging Countries," Journal of Marketing, 76 (6), 21-37.

Miyazaki, Anthony D., Dhruv Grewal, and Ronald C. Goodstein (2005), "The Effect of Multiple Extrinsic Cues on 
Quality Perceptions: A Matter of Consistency," Journal of Consumer Research, 32 (1), 146-53.

Monga, Alokparna Basu, and Deborah Roedder John (2010), "What Makes Brands Elastic? The Influence of Brand Concept and Styles of Thinking on Brand Extension Evaluation," Journal of Marketing, 74 (3), 80-92.

Monga, Alokparna Basu, and Deborah Roedder John (2007), "Cultural Differences in Brand Extension Evaluation: The Influence of Analytic Versus Holistic Thinking," Journal of Consumer Research, 33 (4), 529-36.

Moon, Byeong-Joon, Lee W. Lee, and Chang Hoon Oh (2015), "The Impact of CSR on Consumer-Corporate Connection and Brand Loyalty: A Cross Cultural Investigation," International Marketing Review, 32 (5), 518-39.

Nebenzahl, Israel D., and Eugene D. Jaffe (1996), “Measuring the Joint Effect of Brand and Country Image in Consumer Evaluation of Global Products," International Marketing Review, 13 (4), 5-22.

Ng, Sharon (2010), "Cultural Orientation and Brand Dilution: Impact of Motivation Level and Extension Typicality," Journal of Marketing Research, 47 (1), 186-98.

Ng, Sharon, Hakkyun Kim, and Akshay R. Rao (2015), "Sins of Omission Versus Commission: Cross-Cultural Differences in Brand-Switching Due to Dissatisfaction Induced by Individual Versus Group Action and Inaction," Journal of Consumer Psychology, 25 (1), 89-100.

Nijssen, Edwin J., and Susan P. Douglas (2004), "Examining the Animosity Model in a Country with a High Level of Foreign Trade," International Journal of Research in Marketing, 21 (1), 23-38.

Nijssen, Edwin J., and Susan P. Douglas (2011), "Consumer World-Mindedness and Attitudes Toward Product Positioning in Advertising: An Examination of Global Versus Foreign Versus Local Positioning," Journal of International Marketing, 19 (3), 113-33.

Nisbett, Richard E., Kaiping Peng, Incheol Choi, and Ara Norenzayan (2001), "Culture and Systems of Thought: Holistic Versus Analytic Cognition," Psychological Review, 108 (2), 291-310.

Okazaki, Shintaro (2006), "Excitement or Sophistication? A Preliminary Exploration of Online Brand Personality," International Marketing Review, 23 (3), 279-303.

Okazaki, Shintaro, Barbara Mueller, and Charles R. Taylor (2010), "Global Consumer Culture Positioning: Testing Perceptions of Soft-Sell and Hard-Sell Advertising Appeals Between US and Japanese Consumers," Journal of International Marketing, 18 (2), 20-34.
Özsomer, Aysegül (2012), “The Interplay Between Global and Local Brands: A Closer Look at Perceived Brand Globalness and Local Iconness," Journal of International Marketing, 20 (2), 72-95.

Özsomer, Aysegül, and Selin Altaras (2008), "Global Brand Purchase Likelihood: A Critical Synthesis and an Integrated Conceptual Framework," Journal of International Marketing, $16(4), 1-28$.

Pae, Jae H., Saeed Samiee, and Susan Tai (2002), "Global Advertising Strategy: The Moderating Role of Brand Familiarity and Execution Style," International Marketing Review, 19 (2), 176-89.

Paharia, Neeru, Anat Keinan, Jill Avery, and Juliet B. Schor (2011), "The Underdog Effect: The Marketing of Disadvantage and Determination Through Brand Biography," Journal of Consumer Research, 37 (5), 775-90.

Pan, Yigang, and Bernd Schmitt (1996), "Language and Brand Attitudes: Impact of Script and Sound Matching in Chinese and English," Journal of Consumer Psychology, 5 (3), 263-77.

Pauwels, Koen, Selin Erguncu, and Gokhan Yildirim (2013), "Winning Hearts, Minds and Sales: How Marketing Communication Enters the Purchase Process in Emerging and Mature Markets," International Journal of Research in Marketing, 30 (1), 57-68.

Pecotich, Anthony, and Steven Ward (2007), “Global Branding, Country of Origin and Expertise: An Experimental Evaluation," International Marketing Review, 24 (3), 271-96.

Pesce, Nicole Lyn (2017), "Brands Like Starbucks, Converse and Kiehl's Celebrate Pride Month with Gifts That Give Back," Moneyish (June 19), https://moneyish.com/heart/ brands-like-starbucks-converse-and-kiehls-celebrate-pride-monthwith-gifts-that-give-back/.

Reed, Americus, II, Mark R. Forehand, Stefano Puntoni, and Luk Warlop (2012), "Identity-Based Consumer Behavior," International Journal of Research in Marketing, 29, 310-21.

Riefler, Petra (2012), "Why Consumers Do (Not) Like Global Brands: The Role of Globalization Attitude, GCO and Global Brand Origin," International Journal of Research in Marketing, 29 (1), 25-34.

Roth, Martin S. (1995), "The Effects of Culture and Socioeconomics on the Performance of Global Brand Image Strategies," Journal of Marketing Research, 32 (2), 163-75.

Schmitt, Bernd H., Yigang Pan, and Nader T. Tavassoli (1994), "Language and Consumer Memory: The Impact of Linguistic Differences Between Chinese and English," Journal of Consumer Research, 21 (3), 419-31.

Seo, Yuri, Margo Buchanan-Oliver, and Angela Gracia B. Cruz (2015), "Luxury Brand Markets as Confluences of Multiple 
Cultural Beliefs," International Marketing Review, 32 (2), 141-59.

Sharma, Subhash, Terence A. Shimp, and Jeongshin Shin (1995), "Consumer Ethnocentrism: A Test of Antecedents and Moderators," Journal of the Academy of Marketing Science, 23 (1), 26-37.

Shimp, Terence A., and Subhash Sharma (1987), "Consumer Ethnocentrism: Construction and Validation of the CETSCALE," Journal of Marketing Research, 24 (3), 280-89.

Shrum, Larry J., Tina M. Lowrey, David Luna, D.B. Lerman, and Min Liu (2012), "Sound Symbolism Effects Across Languages: Implications for Global Brand Names," International Journal of Research in Marketing, 29 (3), 275-79.

Siamagka, Nikoletta T., and George Balabanis (2015), "Revisiting Consumer Ethnocentrism: Review, Reconceptualization, and Empirical Testing," Journal of International Marketing, 23 (3), 66-86.

Siamagka, Nikoletta T., George Christodoulides, and Nina Michaelidou (2015), "The Impact of Comparative Affective States on Online Brand Perceptions: A Five-Country Study," International Marketing Review, 32 (3/4), 438-54.

Sichtmann, Christina, and Adamantios Diamantopoulos (2013), "The Impact of Perceived Brand Globalness, Brand Origin Image, and Brand Origin-Extension Fit on Brand Extension Success," Journal of the Academy of Marketing Science, 41 (5), 567-85.

Steenkamp, Jan-Benedict E.M., and Martijn G. de Jong (2010), "A Global Investigation into the Constellation of Consumer Attitudes Toward Global and Local Products," Journal of Marketing, 74 (6), 18-40.

Steenkamp, Jan-Benedict E.M., and Inge Geyskens (2006), "How Country Characteristics Affect the Perceived Value of Web Sites," Journal of Marketing, 70 (3), 136-50.

Strizhakova, Yuliya, and Robin A. Coulter (2013), “The 'Green' Side of Materialism in Emerging BRIC and Developed Markets: The Moderating Role of Global Cultural Identity," International Journal of Research in Marketing, 30 (1), 69-82.

Strizhakova, Yuliya, and Robin A. Coulter (2015), "Drivers of Local Relative to Global Brand Purchases: A Contingency Approach.," Journal of International Marketing, 23 (1), 1-22.

Strizhakova, Yuliya, Robin A. Coulter, and Linda L. Price (2008a), "The Meanings of Branded Products: A CrossNational Scale Development and Meaning Assessment," International Journal of Research in Marketing, 25 (2), 82-93.

Strizhakova, Yuliya, Robin A. Coulter, and Linda L. Price (2008b), "Branded Products as a Passport to Global
Citizenship: Perspectives from Developed and Developing Countries," Journal of International Marketing, 16 (4), 57-85.

Strizhakova, Yuliya, Robin A. Coulter, and Linda L. Price (2011), "Branding in a Global Marketplace: The Mediating Effects of Quality and Self-Identity Brand Signals," International Journal of Research in Marketing, 28 (4), 342-51.

Strizhakova, Yuliya, Robin A. Coulter, and Linda L. Price (2012), "The Young Adult Cohort in Emerging Markets: Assessing Their Glocal Cultural Identity in a Global Marketplace.," International Journal of Research in Marketing, 29 (1), 43-54.

Sung, Yongjun, and Spencer F. Tinkham (2005), "Brand Personality Structures in the United States and Korea: Common and Culture-Specific Factors," Journal of Consumer Psychology, 15 (4), 334-50.

Swaminathan, Vanitha, Karen L. Page, and Zeynep GürhanCanli (2007), “'My' Brand or 'Our' Brand: The Effects of Brand Relationship Dimensions and Self-Construal on Brand Evaluations," Journal of Consumer Research, 34 (2), 248-59.

Swoboda, Bernhard, and Johannes Hirschmann (2016), "Does Being Perceived as Global Pay Off? An Analysis of Leading Foreign and Domestic MNCs in India, Japan, and the United States," Journal of International Marketing, 24 (3), 1-30.

Swoboda, Bernhard, Karin Pennemann, and Markus Taube (2012), "The Effects of Perceived Brand Globalness and Perceived Brand Localness in China: Empirical Evidence on Western, Asian, and Domestic Retailers," Journal of International Marketing, 20 (4), 72-95.

Tavassoli, Nader T., and Jin K. Han (2002), "Auditory and Visual Brand Identifiers in Chinese and English," Journal of International Marketing, 10 (2), 13-28.

Thompson, Craig J., and Zeynep Arsel (2004), “The Starbucks Brandscape and Consumers' (Anticorporate) Experiences of Glocalization," Journal of Consumer Research, 31 (3), 631-42.

Torelli, Carlos, and Rohini Ahluwalia (2012), "Extending Culturally Symbolic Brands: A Blessing or a Curse?" Journal of Consumer Research, 38 (5), 933-47.

Torelli, Carlos J., Aysegül Özsomer, Sergio W. Carvalho, Hean Tat Keh, and Natalia Maehle (2012), "Brand Concepts as Representations of Human Values: Do Cultural Congruity and Compatibility Between Values Matter?" Journal of Marketing, 76 (4), 92-108.

Torres, Anna, Tammo H.A. Bijmolt, Josep A. Tribó, and Peter Verhoef (2012), "Generating Global Brand Equity Through Corporate Social Responsibility to Key Stakeholders," International Journal of Research in Marketing, 29 (1), 13-24. 
Triandis, Harry C., and Michele J. Gelfand (1998), "Converging Measurement of Horizontal and Vertical Individualism and Collectivism," Journal of Personality and Social Psychology, 74 (1), 118-28.

Tse, David K., and Gerald J. Gorn (1993), “An Experiment on the Salience of Country-of-Origin in the Era of Global Brands," Journal of International Marketing, 1 (1), 57-76.

Tse, David K., and Wei-Na Lee (1993), "Removing Negative Country Images: Effects of Decomposition, Branding, and Product Experience," Journal of International Marketing, 1 (94), 25-48.

Tu, Lingjiang, Adwait Khare, and Yinlong Zhang (2012), "A Short 8-Item Scale for Measuring Consumers' Local-Global Identity," International Journal of Research in Marketing, 29 (1), 35-42.

Tucker, Catherine E. (2014), "Social Networks, Personalized Advertising, and Privacy Controls," Journal of Marketing Research, 51 (5), 546-62.

Ulgado, Francis M., and Moonkyu Lee (1993), "Consumer Evaluations of Bi-National Products in the Global Market," Journal of International Marketing, 1 (3), 5-22.

Van der Lans, Rauf, Yvonne van Everdingen, and Valentyna Melnyk (2016), "What to Stress to Whom and Where? A Cross-Country Investigation of the Effects of Perceived Brand Benefits on Buying Intentions," International Journal of Research in Marketing, 33 (4), 924-43.

Wang, Cheng Lu, Terry Bristol, John C. Mowen, and Goutam Chakraborty (2000), "Alternative Modes of Self-Construal: Dimensions of Connectedness-Separateness and Advertising Appeals to the Cultural and Gender-Specific Self," Journal of Consumer Psychology, 9 (2), 107-15.

Westjohn, Stanford A., Mark Arnold, Peter Magnusson, and Kristy Reynolds (2016), "The Influence of Regulatory Focus on Global Consumption Orientation and Preference for Global Versus Local Consumer Culture Positioning," Journal of International Marketing, 24 (2), 22-39.

Westjohn, Stanford A., Nitish Singh, and Peter Magnusson (2012), "Responsiveness to Global and Local Consumer Culture Positioning: A Personality and Collective Identity Perspective," Journal of International Marketing, 20 (1), 58-73.

Whitelock, Jeryl, and Fernando Fastoso (2007), "Understanding International Branding: Defining the Domain and Reviewing the Literature," International Marketing Review, 24 (3), 252-70.
Winit, Warat, Gary Gregory, Mark Cleveland, and Peeter Verlegh (2014), "Global vs Local Brands: How Home Country Bias and Price Differences Impact Brand Evaluations," International Marketing Review, 31 (2), 102-28.

Xie, Yi, Rajeev Batra, and Siqing Peng (2015), “An Extended Model of Preference Formation Between Global and Local Brands: The Roles of Identity Expressiveness, Trust, and Affect," Journal of International Marketing, 23 (1), 50-71.

Yadav, Manjit S., and Paul A. Pavlou (2014), "Marketing in Computer-Mediated Environments: Research Synthesis and New Directions," Journal of Marketing, 78 (1), 20-40.

Yim, Yi-Cheon Mark, Paul L. Sauer, Jerome Williams, Se-Jin Lee, and Iain Macrury (2014), "Drivers of Attitudes Toward Luxury Brands: A Cross-National Investigation into the Roles of Interpersonal Influence and Brand Consciousness," International Marketing Review, 31 (4), 363-89.

Yoon, Yeosun, Zeynep Gürhan-Canli, and Norbert Schwarz (2006), "The Effect of Corporate Social Responsibility (CSR) Activities on Companies with Bad Reputations," Journal of Consumer Psychology, 16 (4), 377-90.

Zeugner-Roth, Katharina Petra, Vesna Zabkar, and Adamantios Diamantopoulos (2015), "Consumer Ethnocentrism, National Identity, and Consumer Cosmopolitanism as Drivers of Consumer Behavior: a Social Identity Theory Perspective," Journal of International Marketing, 23 (2), $25-54$.

Zhang, Shi, and Bernd H. Schmitt (2001), "Creating Local Brands in Multilingual International Markets," Journal of Marketing Research, 38 (3), 313-25.

Zhang, Shi, Bernd Schmitt, and Hillary Haley (2003), "Language and Culture: A New Approach to Consumer Behavior in International Marketing Research," in Handbook of Research in International Marketing, Subhash C. Jain, ed. Northampton, MA: Edward Elgar.

Zhang, Yinlong, and Adwait Khare (2009), "The Impact of Accessible Identities on the Evaluation of Global Versus Local Products," Journal of Consumer Research, 36 (3), 524-37.

Zhou, Lianxi, Zhiyong Yang, and Michael K. Hu (2010), "NonLocal or Local Brands? A Multi-Level Investigation into Confidence in Brand Origin Identification and Its Strategic Implications," Journal of the Academy of Marketing Science, 38 (2), 202-18. 